\title{
Mayer-rokitansky-kuster-hauser syndrome with presacral schwannoma presenting as a pelvic mass: A literature review and case report
}

\author{
Pelvik kitle olarak prezente olan presakral schwannomlu \\ mayer-rokitansky-küster-hauser sendromu ve literatürün \\ gözden geçirilmesi
}

\author{
(1) Raziye Narin ${ }^{1}$, (1) Sefa Özyazıcı ${ }^{2}$, (1) Mehmet Ali Narin ${ }^{3}$, (1) Sevtap Seyfettinoglu ${ }^{3}$, (1) Elife Aşut ${ }^{4}$ \\ 1University of Health Sciences Turkey, Adana City Training and Research Hospital, Clinic of Obstetrics and Gynecology, Adana, Turkey \\ ${ }^{2}$ University of Health Sciences Turkey, Adana City Training and Research Hospital, Clinic of General Surgery, Adana, Turkey \\ 3 University of Health Sciences Turkey, Adana City Training and Research Hospital, Clinic of Gynecological Oncology, Adana, Turkey \\ ${ }^{4}$ University of Health Sciences Turkey, Adana City Training and Research Hospital, Clinic of Pathology, Adana, Turkey
}

\begin{abstract}
A 32-year-old woman was admitted to our gynecology outpatient clinic with primary amenorrhea, a pelvic mass, and pain. Sonographic examination and magnetic resonance imaging revealed an approximately $124 \times 103 \mathrm{~mm}$ heterogeneous mass. Moreover, laparotomy revealed fibrotic uterine bands with normal ovaries, tubes, and a solid retroperitoneal lesion. On the second postoperative day, the mass was removed, and the patient was discharged with full recovery. Microscopic examination of the pelvic mass confirmed the diagnosis of schwannoma. To the best of our knowledge, this is the first report on the co-occurrence of Mayer-Rokitansky-Küster-Hauser syndrome and schwannoma, without the presence of any other pathology.

Keywords: MRKH syndrome, schwannoma, pelvic mass
\end{abstract}

Öz

Pelvik kitle olarak prezente olan presakral schwannomlu Mayer-Rokitansky-Küster-Hauser sendromu (MRKHS). MRKH'li hastalar sıklıkla ekstragenital anomaliler, özellikle ürolojik ve iskelet anomalileri sergiler. Hastamız, schwannomanın eşlik ettiği ilk MRKHS olgusudur. Otuz iki yaşında kadın hasta jinekoloji polikliniğimize primer amenore, pelvik kitle ve ağrı şikayetleri ile başvurdu. Sonografik değerlendirme ve manyetik rezonans görüntülemede, yaklaşı 124×103 mm'lik heterojen bir kitle görünümü mevcuttu. Laparotomide fibrotik uterin bantlara eşlik eden normal overler, tubalar ve sert bir retroperitoneal lezyon izlendi. Kitle ekstirpe edildi ve postoperatif ikinci günde hasta şifa ile taburcu edildi. Pelvik kitlenin mikroskobik incelemesi schwannoma tanısını doğruladı. Bilgilerimize göre bu iki malformasyonun herhangi bir ek patoloji olmaksızın birlikte ortaya çıktığı ilk olgudur.

Anahtar Kelimeler: MRKH sendromu, schwannoma, pelvik kitle

\section{Introduction}

Vaginal agenesis, also known as Mullerian aplasia or MayerRokitansky-Küster-Hauser (MRKH) syndrome, is characterized by congenital absence of the vagina and variable uterine development. It results from agenesis or hypoplasia of the Mullerian duct system; however, the underlying etiology remains unknown. The incidence of MRKH syndrome has been estimated to be 1 in every 4.500 female births ${ }^{(1)}$. Most of the cases appear to be sporadic; however, cases having a family history of this disease have also been described. The first clinical signal is generally primary amenorrhea in patients who have a normal female phenotype, a normal 46 XX karyotype, and normal and functioning ovaries with no signs of androgen excess $^{(2)}$. Furthermore, external examination of these patients reveals completed puberty with normal secondary female sexual characteristics (pubic hair and breast development: Tanner stage 5) and normal external genitalia.

Schwannomas are rare tumors of ectodermic origin that grow from the neural sheath and are usually found in the neck and

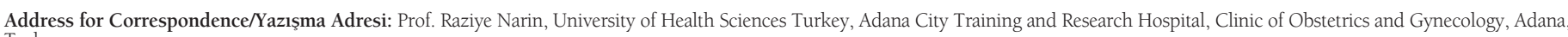
Turkey

Phone: +90 3224559000 E-mail: ryencilek@yahoo.com.tr ORCID ID: orcid.org/0000-0001-5352-878X

Received/Geliş Tarihi: 03.05.2021 Accepted/Kabul Tarihi: 02.07.2021

${ }^{\circledR}$ Copyright 2021 by Turkish Society of Obstetrics and Gynecology

Turkish Journal of Obstetrics and Gynecology published by Galenos Publishing House. 
extremities. These tumors commonly arise from the cranial nerves as acoustic neurinomas, but they are extremely rare in the pelvis and retroperitoneal area (less than $0.5 \%$ of reported cases), unless they are associated with von Recklinghausen disease (type 1 neurofibromatosis) (3). Schwannomas are mostly benign in nature and are more common in adult females between the age of 20 and 50 years, with a male-to-female ratio of 2:3. Preoperative biopsy examinations can be challenging, and immunohistochemistry is necessary for the correct diagnosis of a schwannoma ${ }^{(4)}$. Further, a low rate of mitosis and the absence of atypical mitotic figures and nuclear hyperpigmentation characterize a benign lesion.

To the best of our knowledge, this is the first report on the cooccurence of MRKH syndrome and schwannoma in adulthood, without any other pathology, such as genitourinary system abnormalities, skeletal anomalies, or deafness.

\section{Case Presentation}

A 32-year-old virgin female patient was admitted to our gynecology clinic with primary amenorrhea and pain. Her family history was unremarkable. Abdominal examination revealed a rigid and fixed mass extending to the level of the umbilicus, with no visceromegaly or ascites. During the pelvic examination, the external genitalia were normal, but there was vaginal agenesis (Figure 1A). In addition, breast development was normal (Tanner stage 5). Ultrasound imaging revealed a $124 \times 103 \mathrm{~mm}$ heterogeneous mass, and an abdominal magnetic resonance scan revealed a $130 \times 100 \mathrm{~mm}$ mass lesion located in the presacral region and compressing the bladder posteriorly. However, the patient had no complaints related to defecation or miction. Furthermore, all laboratory findings were normal

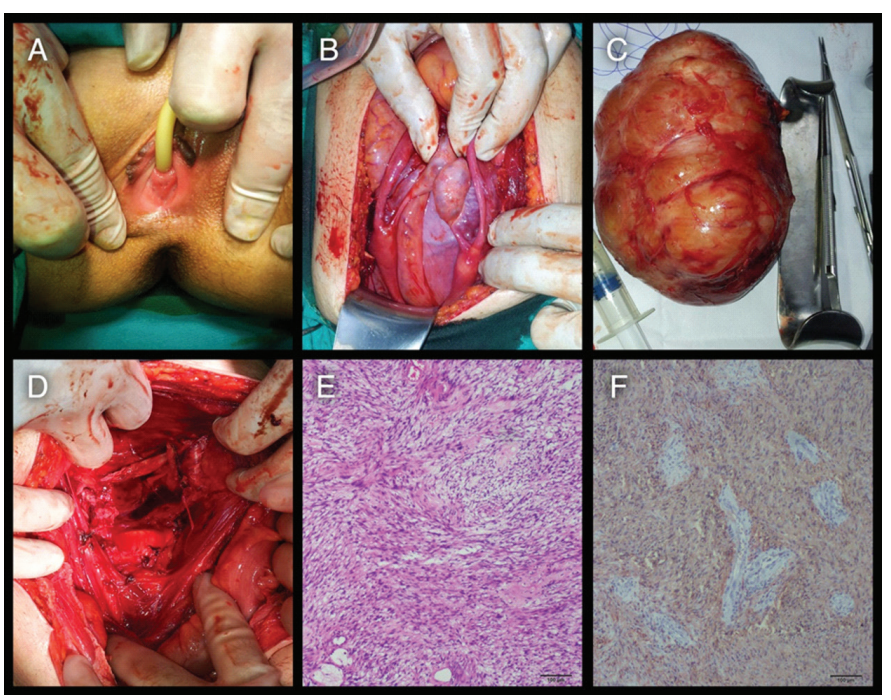

Figure 1. External genitalia (A), internal genitalia and the pelvic mass (B), appearance of specimen (C), retroperitoneal area after mass removal (D), histological appearance of schwannoma, spindle cell neoplasm composed of cellular and hypocellular areas (H\&E 100x) (E), and S100 immunostaining of Schwann cells immunohistochemistry 100x (F) (follicle stimulating hormone: $7.9 \mathrm{mIU} / \mathrm{mL}$, luteinizing hormone: $14.5 \mathrm{mIU} / \mathrm{mL}$, estradiol: $200 \mathrm{pg} / \mathrm{mL}, \mathrm{Ca}-125: 12.2 \mathrm{U} /$ $\mathrm{mL}, \mathrm{CA}$ 19-9: $8.0 \mathrm{U} / \mathrm{mL}, \mathrm{CA}$ 15-3: $7.4 \mathrm{U} / \mathrm{mL}$, and hemoglobin: $14 \mathrm{~g} / \mathrm{dL})$.

The patient underwent laparatomy under general anesthesia. The tubes and ovaries were normal, but the uterus was seen as two distinct tubular-shaped fibrotic bands (Figure 1B). Behind the internal genital organs, a solid and fixed mass was discovered (Figure 1B). This mass was extirpated by a general surgeon (Figure 1C, D). There was no complication in the postoperative period and she was discharged on the second postoperative day.

A schwannoma was discovered during the pathological examination of the specimen (Figure 1E, F). Immunohistochemical markers showed a diffuse positivity of S-100, actine (-), desmin (-), Kì-67: 3\%, and CD34 (-).

The patient was asked to sign a consent form for publication.

\section{Discussion}

Women with MRKH syndrome have a normal female karyotype, with normal ovaries and ovarian functions, and thus they develop normal secondary sexual characteristics (e.g., breasts, axillary hair, and pubic hair). However, these women have a congenital absence of the uterus, cervix, and upper part of the vagina.

In the literature search we conducted using the keywords "MRKH syndrome" and "pelvic mass," very few case reports were found. In most of these cases, the pelvic mass was found to be a leiomyoma. They reported that despite the low probability of having fibroids without a uterus, fibroids should not be ruled out in such patients ${ }^{(5,6)}$.

It is known that urinary system anomalies are frequently observed in patients with MRKH syndrome. Karimbayev et al. ${ }^{(7)}$ presented a 14-year-old patient with MRKH syndrome and pelvic ectopic kidney as a pelvic mass in their study.

Bae et al. ${ }^{(8)}$ reported the first known case of cancer of the supernumerary ovary in a patient with MRKH syndrome, and they proposed that although both ovaries were confirmed to be normal in the patient with MRKH syndrome, ovarian neoplasm should be considered in the diagnosis of a pelvic mass.

Juusela et al. ${ }^{(9)}$ presented two rare pathologies, bilateral Sertoli cell tumors of the ovary and MRKH syndrome, which developed concomitantly in the same patient.

In a study carried out by Kawano et al. ${ }^{(10)}$, bilateral Mullerian remnants with functioning endometrium and a pelvic mass that was considered an endometriotic cyst were revealed on magnetic resonance imaging. Table 1 shows the author's name, publication year, and the diagnosis of accompanying pelvic masses in patients with MRKH syndrome $e^{(11-20)}$

To the best of our knowledge, this is the first case in which MRKH syndrome and schwannoma are seen together. MRKH syndrome is mainly sporadic, but it may be an inherited disorder. The genetic defects responsible for MRKH syndrome remain unclear. Furthermore, a recent study investigated male 
Table 1. Author's name, publication year, and the diagnosis of accompanying pelvic masses in patients with MRKH syndrome

\begin{tabular}{lll} 
Author & Publication & Diagnosis \\
\hline Papa et al. ${ }^{(11)}$ & 2008 & Leiomyoma \\
${\text { Lanowska et al. }{ }^{(12)}}$ & 2009 & Leiomyoma \\
Fletcher et al. $^{(13)}$ & 2012 & Leiomyoma \\
Bae et al. ${ }^{(8)}$ & 2013 & Cancer of the \\
Kawano et al. ${ }^{(10)}$ & 2014 & supernumerary ovary \\
Girma and Woldeyes. ${ }^{(14)}$ & 2015 & Leiomyoma \\
Hasegawa et al. ${ }^{(15)}$ & 2015 & Leiomyoma \\
Narayanan et al. ${ }^{(16)}$ & 2015 & Leiomyoma \\
Dimitriadis et al. ${ }^{(17)}$ & 2016 & Mitotically active \\
Karimbayev et al. ${ }^{(7)}$ & 2018 & leiomyoma \\
Juusela et al. ${ }^{(9)}$ & 2018 & Belvic ectopic kidney \\
Jokimaa et al. ${ }^{(18)}$ & 2020 & cell tumors \\
Romano et al. ${ }^{(19)}$ & 2021 & Leiomyoma \\
Ibidapo-Obe et al. ${ }^{(20)}$ & 2021 & Leiomyoma \\
MRKH: Mayer-Rokitansky-Küster-Hauser &
\end{tabular}

microchimerism as a possible cause but found no evidence to support this finding ${ }^{(21)}$. Schwannomas may occur spontaneously or in the context of a familial tumor syndrome, such as neurofibromatosis type $1^{(22)}$. Retroperitoneal schwannomas are extremely rare tumors that are difficult to diagnose preoperatively ${ }^{(23)}$.

Besides MRKH syndrome and retroperitoneal schwannoma, our patient had no other conditions. Moreover, genetic studies could not be carried out. Therefore, we do not know if there is a common genetic defect that can cause both disorders. However, since the presented case is unique in the literature, it appears unlikely that a common genetic defect exists.

Treatment for MRKH syndrome involves a combination of psychosocial support and correction of anatomical defects, such as the creation of a functional vagina and transplantation of a uterus. In our case, since the patient is not married and her primary complaint was pelvic pain, we only surgically removed the mass. She was relieved after the surgery, and since the pathological diagnosis was benign schwannoma, no further treatment was required. At a 6-month postoperative followup, the patient was completely asymptomatic, and computed tomography scan imaging revealed no mass.

\section{Conclusion}

We present a unique case of MRKH syndrome with a schwannoma. To treat pelvic masses with Mullerian congenital anomalies, accurate evaluation and informed consent are required prior to surgery.

\section{Ethics}

Informed Consent: The patient was asked to sign a consent form for publication

Peer-review: Externally and internally peer-reviewed. Authorship Contributions

Surgical and Medical Practices: R.N., S.Ö., M.A.N., S.S., E.A., Concept: R.N., S.Ö., M.A.N., S.S., E.A., Design: R.N., S.Ö., M.A.N., S.S., E.A., Data Collection or Processing: R.N., S.Ö., M.A.N., S.S., E.A., Analysis or Interpretation: R.N., S.Ö., M.A.N., S.S., E.A., Literature Search: R.N., S.Ö., M.A.N., S.S., E.A., Writing: R.N., S.Ö., M.A.N., S.S., E.A.

Conflict of Interest: The authors declare no conflict of interest. Financial Disclosure: The authors declared that this study received no financial support.

\section{References}

1. Folch M, Pigem I, Konje JC. Mullerian agenesis: etiology, diagnosis, and management. Obstet Gynecol Surv 2000;55:644-9.

2. Shane JM, Wilson EA, Schiff I, Naftolin F. A preliminary report on gonadotropin responsivity in the Rokitansky-Kuster-Hauser syndrome (congenitally absent uterus). Am J Obstet Gynecol 1977;127:326-7.

3. Dawley B. A retroperitoneal femoral nerve schwannoma as a cause of chronic pelvic pain. J Minim Invasive Gynecol 2008;15:491-3.

4. Bugıantella W, Rondelli F, Mariani L, Peppoloni L, Cristallini E, Mariani E. Schwannoma of the colon: a case report. Oncol Lett 2014;8:2511-2

5. Blontzos N, Iavazzo C, Vorgias G, Kalinoglou N. Leiomyoma development in Mayer-Rokitansky-Küster-Hauser syndrome: a case report and a narrative review of the literature. Obstet Gynecol Sci 2019;62:294-7.

6. Ibidapo-Obe $\mathrm{O}$, Okudo J, Filani O. Incidental finding of leiomyoma in Mayer-Rokitansky-Kuster-Hauser syndrome. J Investig Med High Impact Case Rep 2021;9:23247096211014690. doi: $10.1177 / 23247096211014690$.

7. Karimbayev K, Dzumanazarov N, Akhaibekov M, Berdikulov N, Karimbayev A, Mustafayev A. Pelvic dystopia of right rudimentary multicystic dysplastic kidney as a rare cause of bedwetting in a patient with a single pelvic ectopic left kidney, and agenesis of the uterus and vagina (Mayer-Rokitansky-Küster-Hauser syndrome): a case report. J Med Case Rep 2018;12:121.

8. Bae HS, Ryu MJ, Kim IS, Kim SH, Song JY. Cancer of the supernumerary ovary in Mayer-Rokitansty-Küster-Hauser syndrome: a case report. Oncol Lett 2013;5:598-600.

9. Juusela AL, Naghi I, Thani S. Mayer-Rokitansky-Küster-Hauser syndrome with bilateral ovarian sertoli cell tumors: review of the literature and report of a rare case. Female Pelvic Med Reconstr Surg 2018;24:e32-4. doi: 10.1097/SPV.0000000000000483. PMID: 28922305.

10. Kawano Y, Hirakawa T, Nishida M, Yuge A, Yano M, Nasu K, et al. Functioning endometrium and endometrioma in a patient with mayer-rokitanski-kuster-hauser syndrome. Jpn Clin Med 2014;5:43-5.

11. Papa G, Andreotti M, Giannubilo SR, Cesari R, Ceré I, Tranquilli AL. Case report and surgical solution for a voluminous uterine 
leiomyoma in a woman with complicated Mayer-RokitanskyKüster-Hauser syndrome. Fertil Steril 2008;90:2014.e5-6. doi: 10.1016/j.fertnstert.2008.04.061.

12. Lanowska M, Favero G, Schneider A, Köhler C. Laparoscopy for differential diagnosis of a pelvic mass in a patient with MayerRokitanski-Küster-Hauser (MRKH) syndrome. Fertil Steril 2009;91:931.

13. Fletcher HM, Campbell-Simpson K, Walcott D, Harriott J. Müllerian remnant leiomyomas in women with Mayer-Rokitansky-KüsterHauser syndrome. Obstet Gynecol 2012;119:483-5.

14. Girma W, Woldeyes W. Leiomyoma arising from mullerian remnant, mimicking ovarian tumor in a woman with MRKH syndrome and unilateral renal agenesis. Ethiop J Health Sci 2015;25:381-4. doi: 10.4314/ejhs.v25i4.14.

15. Hasegawa A, Igarashi H, Ohta T, Kurachi H, Takahashi K. Threedimensional computed tomography of pelvic masses in MayerRokitansky-Küster-Hauser syndrome. Obstet Gynecol 2015 Feb;125(2):393-396.

16. Narayanan R, Mariappan S, Paulraj S, Shankar B. Imaging of leiomyomas arising from Müllerian remnants in a case of Mayer-Rokitansky-Küster-Hauser syndrome. BMJ Case Rep 2015;2015:bcr2015210737. doi: 10.1136/bcr-2015-210737.

17. Dimitriadis I, Pagidas K, Vaughan D, Kim YB. Mitotically active leiomyoma in a woman with Mayer-Rokitansky-Küster-Hauser syndrome: a case report. J Reprod Med 2016;61:299-301.
18. Jokimaa V, Virtanen J, Kujari H, Ala-Nissilä S, Rantanen V. A MayerRokitansky-Kuster-Hauser patient with leiomyoma and dysplasia of neovagina: a case report. BMC Womens Health 2020;20:157.

19. Romano F, Carlucci S, Stabile G, Mirenda G, Mirandola M, Mangino FP, et al. The Rare, unexpected condition of a twisted leiomyoma in mayer-rokitansky-küster-hauser (MRKH) syndrome: etiopathogenesis, diagnosis and management. Our experience and narrative review of the literature. Int J Environ Res Public Health 2021;18:5895.

20. Ibidapo-Obe O, Okudo J, Filani O. Incidental finding of leiomyoma in mayer-rokitansky-kuster-hauser syndrome. J Investig Med High Impact Case Rep 2021;9:23247096211014690. doi: 10.1177/23247096211014690.

21. Peters HE, Johnson BN, Ehli EA, Micha D, Verhoeven MO, Davies $\mathrm{GE}$, et al. Low prevalence of male microchimerism in women with Mayer-Rokitansky-Küster-Hauser syndrome. Hum Reprod 2019;34:1117-25.

22. Bikowska- Opalach B, Jackowska T. Neurofibromatosis type 1 description of clinical features and molecular mechanism of the disease. Med Wieku Rozwoj 2013;17:334-40.

23. Goh BK, Chung YF, Chow PKH, Ooi LLPJ, Wong WK. Retroperitnoeal schwannoma. Am J Surg 2006;192:14-8. 